\title{
ANALISIS PENGARUH PRESTASI KERJA KARYAWAN TERHADAP PROMOSI JABATAN PADA PERUSAHAAN DAERAH AIR MINUM (PDAM) KABUPATEN BANGGAI
}

\author{
JURTAN LATUBA,S.E.,M.Si \\ Dosen Fakultas Ekonomi Universitas Muhammadiyah Luwuk \\ Email : jurtan_latuba@yahoo.co.id \\ Hp : 082292505389 \\ IRWAN MORIDU, S.E.,M.M \\ Dosen Fakultas Ekonomi Universitas Muhammadiyah Luwuk \\ Email : irwanmoridu@gmail.com \\ Hp : 0811452424
}

\begin{abstract}
ABSTRAK
Perusahaan Daerah Air Minum (PDAM) Kabupaten Banggai dituntut untuk memberikan kinerja yang optimal dalam pelaksanaan perencanaan pembangunan daerah. Untuk mencapai efektivitas dalam melaksanakan tugas, karyawan perlu memiliki komitmen yang tinggi terhadap tugas dan organisasi. Komitmen karyawan terhadap organisasi akan meningkatkan tanggung jawab dan kesungguhan karyawan dalam melaksanakan tugas. Karyawan dengan komitmen kerja yang tinggi akan bekerja sepenuh hati dan akan berjuang demi meingkatkan prestasi kerjanya. Karyawan Perusahaan Daerah Air Minum (PDAM) Kabupaten Banggai akan memiliki prestasi kerja yang lebih tinggi ketika bekerja, lebih optimal kinerjanya, efisien dan efektif dalam menghadapi dan menyelesaikan pekerjaannya. Dengan tingginya prestasi kerja karyawan Perusahaan Daerah Air Minum (PDAM) Kabupaten Banggai maka pimpinan dapat mengetahui seberapa mampu karyawan mengerjakan tugas dan tanggung jawab yang diberikan kepadanya. Dengan demikian instansi dapat menentukan balas jasa yang layak baginya.

Tujuan dari penelitian ini adalah Untuk mengetahui apakah prestasi kerja memiliki pengaruh yang positif dan signifikan terhadap promosi jabatan pada Perusahaan Daerah Air Minum (PDAM) Kabupaten Banggai.Target peneltian ini diharapkan Mendapatkan pengetahuan secara mendetail terkait tentang Promosi jabatan yang terjadi pada lingkup Perusaahan Air Minum Daerah (PDAM) Kabupaten Banggai. Serta Mendapatkan pengetahuan lebih terperinci terkait tugas dan tanggungjawab yang ada pada seorang yang mendapatkan Promosi jabatan dri hasil Prestasi kerja. Metode yang digunakan dalam penelitian adalah metode empiris dengan menggunakan populasi dan sampel dengan teknik pengumpulan data kualitatif dan kuantitatif, yaitu data yang diperoleh dari perusahaan dalam bentuk angka-angka.
\end{abstract}

Kata Kunci : Prestasi Kerja,Promosi Jabatan 


\begin{abstract}
Regional Water Company (PDAM) of Banggai Regency is required to provide optimal performance in the implementation of regional development planning. To achieve effectiveness in carrying out the task, employees need to have a high commitment to the task and organization. Employee commitment to the organization will increase the responsibility and seriousness of employees in carrying out the task. Employees with high work commitment will work wholeheartedly and will strive to improve their work performance. The employees of the Regional Water Company (PDAM) of Banggai Regency will have higher work performance while working, more optimally performing, efficiently and effectively in dealing with and completing their work. With the high performance of employees of Regional Water Company (PDAM) Banggai Regency then the leader can find out how capable employees do the tasks and responsibilities given to him. Thus the agency can determine the appropriate remuneration for him.

The purpose of this study is to determine whether job performance has a positive and significant influence on promotion of positions in the Regional Water Supply Company (PDAM) Banggai Regency.Target of this study is expected to Gain detailed knowledge related to Promotion of positions that occurred in the scope of Regional Water Supply (PDAM) of Banggai Regency. And Gain more detailed knowledge related tasks and responsibilities that exist in a person who gets Promotion job results dri results. The method used in research is empirical method by using population and sample with qualitative and quantitative data collection technique, that is data obtained from company in the form of numbers.
\end{abstract}

Keywords: Job Performance, Job Promotion

\title{
LATAR BELAKANG
}

Pengembangan SDM merupakan cara organisasi agar dapat mempertahankan eksistensi kerja semua komponen organisasi. Sebuah organisasi harus mampu mengoptimalkan kemampuan sumber daya manusia yang dimilikinya agar pencapaian sasaran dapat terlaksana, namun hal tersebut tidaklah sederhana perlu pemahaman yang baik tentang organisasi, perlu ada strategi pengembangan yang matang agar SDM yang dimiliki sebuah organisasi terpakai sesuai kebutuhan.Pengembangan SDM dapat dilakukan dengan berbagai cara, salah-satunya adalah dengan melalui promosi jabatan. Dengan adanya target promosi, karyawan akan merasa dihargai, diperhatikan, dibutuhkan dan diakui kemampuan kerjanya oleh atasan sehingga mereka akan menghasilkan keluaran (output) yang tinggi.

Promosi jabatan dilaksanakan untuk mengoptimalkan sumber daya manusia yang dimiliki organisasi, selain itu promosi jabatan bertujuan untuk meregenerasi sumber daya manusia dalam organisasi demi kelangsungan organisasi tersebut. Penilaian prestasi kerja terhadap karyawan merupakan tolak ukur utama dalam pengembangan SDM. Perusahaan Daerah Air Minum (PDAM) Kabupaten Banggai dituntut untuk memberikan kinerja yang 
optimal dalam pelaksanaan perencanaan pembangunan daerah. Untuk mencapai efektivitas dalam melaksanakan tugas, karyawan perlu memiliki komitmen yang tinggi terhadap tugas dan organisasi. Komitmen karyawan terhadap organisasi akan meningkatkan tanggung jawab dan kesungguhan karyawan dalam melaksanakan tugas. Karyawan dengan komitmen kerja yang tinggi akan bekerja sepenuh hati dan akan berjuang demi meingkatkan prestasi kerjanya. Karyawan Perusahaan Daerah Air Minum (PDAM) Kabupaten Banggai akan memiliki prestasi kerja yang lebih tinggi ketika bekerja, lebih optimal kinerjanya, efisien dan efektif dalam menghadapi dan menyelesaikan pekerjaannya. Dengan tingginya prestasi kerja karyawan Perusahaan Daerah Air Minum (PDAM) Kabupaten Banggai maka pimpinan dapat mengetahui seberapa mampu karyawan mengerjakan tugas dan tanggung jawab yang diberikan kepadanya. Dengan demikian instansi dapat menentukan balas jasa yang layak baginya.

Promosi merupakan kesempatan untuk berkembang dan maju yang dapat mendorong karyawan untuk lebih baik atau lebih bersemangat dalam melakukan suatu pekerjaan dalam lingkungan organisasi. Dengan adanya target promosi, pasti karyawan akan merasa dihargai, diperhatikan, dibutuhkan dan diakui kemampuan kerjanya oleh manajemen organisasi sehingga mereka akan menghasilkan keluaran (output) yang tinggi serta akan mempertinggi loyalitas (kesetiaan) pada organisasi.

Oleh karena itu, pimpinan Perusahaan Daerah Air Minum (PDAM) Kabupaten Banggai harus menyadari pentingnya promosi dalam peningkatan kinerja yang harus dipertimbangkan secara objektif. Jika pimpinan telah menyadari dan mempertimbangkan, maka organisasi akan terhindar dari masalah-masalah yang menghambat peningkatan keluaran dan dapat merugikan organisasi seperti: ketidak puasan karyawan, adanya keluhan, tidak adanya semangat kerja, menurunnya disiplin kerja, tingkat absensi yang tinggi atau bahkan masalah-masalah pemogokan kerja. Promosi jabatan merupakan sarana yang dapat mendorong karyawan untuk lebih baik atau lebih bersemangat dalam melakukan suatu pekerjaan dalam lingkungan organisasi. Dengan melihat fakta tersebut maka prestasi kerja yang mengarah pada promosi jabatan harus dilakukan dengan efektif agar dapat diterima semua pihak tanpa ada yang merasa dirugikan. Prestasi kerja dan promosi jabatan sangat erat kaitanya dan juga menjadi hal sensitif dalam organisasi. Untuk dapat memutuskan imbalan yang sepenuhnya diberikan kepada seorang karyawan atas hasil kerjanya, maka perusahaan harus memiliki sesuatu sistem balas jasa yang tepat.

Mekanisme untuk dapat menentukan balas jasa yang pantas bagi suatu prestasi kerja adalah dengan prestasi kerja. Prestasi kerja juga dapat digunakan perusahaan untuk 
mengetahui kekurangan dan potensi seorang karyawan. Dari hasil tersebut, perusahaan dapat mengembangkan suatu perencanaan sumber daya manusia secara menyeluruh dalam menghadapi masa depan perusahaan. Prinsip "The right man in the right place" harus dipenuhi agar perusahaan dapat berjalan dengan efisien dan efektif. Mengingat pentingnya pengaruh prestasi kerja ini dalam keputusan mengenai promosi karyawan, Selanjutnya muncul suatu persoalan pada saat dihadapkan pada prestasi kerja, masih banyaknya karyawan Perusahaan Daerah Air Minum (PDAM) Kabupaten Banggai bekerja dengan seenaknya, kurang memanfaatkan waktu yang ada untuk mengembangkan diri, lebih suka berbincang-bincang dengan rekan sekerja dari pada menyelesaikan karyawan, sehingga hal ini akan mempengaruhi prestasi kerjanya. Sehingga banyak karyawan Perusahaan Daerah Air Minum (PDAM) Kabupaten Banggai yang jarang mendapatkan promosi jabatan ke tingkat yang lebih tinggi.

Dari latar belakang pemikiran di atas, maka penulis berniat untuk menulis sebuah penelitian yang berjudul "AnalisisPengaruh Prestasi Kerja Karyawan Terhadap Promosi Jabatan Pada Perusahaan Daerah Air Minum (PDAM) Kabupaten Banggai”.

\section{RUMUSAN MASAALAH}

Berdasarkan latar belakang tersebut di atas, maka masalah penelitian dirumuskan sebagai berikut apakah prestasi kerja memiliki pengaruh positif dan signifikan terhadap promosi jabatan pada Perusahaan Daerah Air Minum (PDAM) Kabupaten Banggai.

\section{TUJUAN DAN KEGUNAAN PENELITIAN}

1. Tujuan Penelitian adalah

Untuk mengetahui apakah prestasi kerja memiliki pengaruh yang positif dan signifikan terhadap promosi jabatan pada Perusahaan Daerah Air Minum (PDAM) Kabupaten Banggai.

2. Kegunaan Penelitian

a. Bagi peneliti berikutnya, hasil penelitian ini dapat dipergunakan sebagai bahan informasi dan pertimbangan apabila ingin meneliti lebih lanjut mengenal promosi jabatan.

b. Sebagai bahan masukan bagi Perusahaan Daerah Air Minum (PDAM) Kabupaten Banggai agar dapat mengetahui hal-hal yang berkaitan dengan prestasi kerja karyawan dan promosi jabatan. 


\section{METODE PENELITIAN}

\section{Jenis Penelitian}

Jenis Penelitian ini adalah penelitian yang menggunakan metode Empiris dengan menggunakan populasi dan sampel. Yang dimaksud dengan populasi adalah keseluruhan objek penelitian (Arikunto, 2001). Populasi penelitian ini adalah 128 orang karyawan PDAM Kabupaten Banggai, penulis beranggapan bahwa karyawan berperan aktif untuk melaksanakan kegiatan serta memikirkan bagaimana melakukan pelayanan kepada masyarakat.

\section{Tekhnik Pengumpulan Data}

Metode yang digunakan dalam pengumpulan data, adalah sebagai berikut :

1. Kuesioner

Yaitu sejumlah daftar pertanyaan yang diajukan oleh peneliti untuk mendapatkan informasi yang mendasarkan dari laporan tentang diri sendiri (self report) atau pada pengetahuan dan atau keyakinan pribadi subyek atau informasi yang diteliti (Arikunto, 2002). Kuesioner ini dimaksudkan untuk memperoleh data deskriptif guna menguji hipotesis dan model kajian. Untuk memperoleh data tersebut digunakan kuesioner yaitu pertanyaan yang dibuat sedemikian rupa hingga responden dibatasi dalam memberi jawaban kepada beberapa alternatif saja atau kepada satu jawaban saja.

2. Studi Dokumentasi

Yaitu mengumpulkan informasi dengan mempelajari sumber data tertulis untuk memperoleh data sekunder mengenai hasil prestasi kerja karyawan, sejarah organisasi, jumlah karyawan, struktur organisasi, dan data tertulis lainnya yang ada hubungannya dengan penelitian ini.

Pengukuran variabel digunakan metode Likerts Summated ratings (LSR). Dengan alternatif pilihan 1 sampai 5 jawaban pertanyaan dengan ketentuan sebagai berikut:

Nilai 5: Untuk jawaban sangat setuju artinya responden sangat setuju dengan pertanyaan karena sangat sesuai dengan keadaan yang dirasakan oleh responden.

Nilai 4: Untuk jawaban setuju artinya pertanyaan dianggap sesuai dengan keadaan yang dirasakan oleh responden.

Nilai 3: Untuk jawaban ragu-ragu artinya tidak dapat menetukan atau apabila responden tidak dapat menentukan dengan pasti apa yang dirasakan.

Nilai 2: Untuk jawaban tidak setuju artinya responden tidak setuju dengan pertanyaan karena tidak sesuai dengan apa yang dirasakan. 
Nilai 1: Untuk jawaban sangat tidak setuju artinya pertanyaan sangat tidak sesuai dengan keadaan yang dirasakan oleh responden.

\section{Metode Analisa Data}

1. Uji Validitas dan Reliabilitas

a. Uji Validitas

Uji validitas menunjukkan sejauh mana suatu alat pengukur itu mengukur apa yang ingin diukur. Uji validitas digunakan oleh peneliti untuk mengukur data yang telah didapat setelah penelitian yang merupakan data yang valid dengan alat ukur yang digunakan yaitu kuesioner. Jika instrumen itu valid, maka kriteria yang digunakan atau batas minimum suatu instrumen/angket atau bahan tes dinyatakan valid atau dianggap memenuhi syarat, jika harga koefisien $r$ hitung $>0,30$ (Sugiyono: 2005), dalam menentukan validitas suatu kuesioner adalah sebagai berikut:

1) Sebuah instrumen pengukuran dapat dikatakan valid jika instrumen tersebut memberikan hasil ukur yang sesuaidengan maksud dilakukannya pengukuran.

2) Pengertian validitas adalah sejauh mana suatu alat pengukur itu mengukur apa yang ingin di ukur.

3) Validitas suatu instrumen dinyatakan dalam nilai-nilai hasil analisis skor tiap butir terhadap nilai totalnya. Apabila nilai skor totalnya menunjukan positif berarti butir tersebut menunjukan korelasi yang valid pada taraf signifikan $5 \%(0,05)$.

Uji validitas dilakukan pada Perusahaan Daerah Air Minum (PDAM) Kabupaten Banggai dengan memberikan kuesioner kepada 56 orang karyawan tetap sesuai dengan kriteria yang ditentukan sebagai responden. Pengujian validitas menggunakan bantuan program SPSS 19.0 for windows.

\section{PEMBAHASAN}

\section{Hasil Penelitian}

Sehubungan dengan penelitian tentang pengaruh prestasi kerja Terhadap promosi jabatan pada PDAM Kabupaten Banggai, maka penulis mengambil langkah-langkah dengan mengumpulkan data mengenai variabel prestasi kerja dan promosi jabatan. Untuk mengolah data tersebut, berdasarkan jawaban yang diberikan responden, kemudian disajikan dalam tabel distribusi frekuensi seperti dijelaskan dibawah ini :

1. Daftar Isian Tabel Kuesioner Responden

a. Prestasi Kerja Karyawan(X) 
Tabel 4.1.

Distribusi Frekuensi Tanggapan Responden Tentangkaryawan menyelesaikan pekerjaan sesuai dengan waktu kerja yang tekah ditentukan

\begin{tabular}{|c|c|c|c|}
\hline No & Jawaban Responden & Frekuensi & Persentase \\
\hline 1. & Sangat Setuju & 27 & $48.21 \%$ \\
\hline 2. & Setuju & 21 & $37.50 \%$ \\
\hline 3. & Ragu - Ragu & 5 & $8.93 \%$ \\
\hline 4. & Tidak Setuju & 3 & $5.36 \%$ \\
\hline 5. & Sangat Tidak Setuju & - & - \\
\hline \multicolumn{2}{|r|}{ Jumlah } & 56 & $100 \%$ \\
\hline
\end{tabular}

Dari tabel 4.1 diatas menunjukan tanggapan responden adalah sangat setuju jika karyawan menyelesaikan pekerjaan sesuai dengan waktu kerja yang tekah ditentukan. Hal ini terlihat pada jawaban responden dimana 27 orang atau 48,21\% yang menjawab sangat setuju, 21 orang atau 37,50\% menjawab setuju, 5 orang atau 8,93\% menjawab ragu-ragu, dan 3 orang 5,36\% menjawab tidak setuju jika karyawan menyelesaikan pekerjaan sesuai dengan waktu kerja yang tekah ditentukan.

Tabel 4.2.

Distribusi Frekuensi Tanggapan Responden Tentang karyawan bekerja selalu memperhatikan ketepatan, ketelitian, ketrampilan, kebersihan hasil kerja

\begin{tabular}{|c|c|c|c|}
\hline No & Jawaban Responden & Frekuensi & Persentase \\
\hline 1. & Sangat Setuju & 20 & $35.71 \%$ \\
\hline 2. & Setuju & 22 & $39.29 \%$ \\
\hline 3. & Ragu - Ragu & 10 & $17.86 \%$ \\
\hline 4. & Tidak Setuju & 4 & $7.14 \%$ \\
\hline 5. & Sangat Tidak Setuju & - & - \\
\hline \multicolumn{2}{|r|}{ Jumlah } & 56 & $100 \%$ \\
\hline
\end{tabular}

Dari tabel 4.2 diatas menunjukan tanggapan responden adalah setuju jika karyawan bekerja selalu memperhatikan ketepatan, ketelitian, ketrampilan, kebersihan hasil kerja. Hal ini terlihat pada jawaban responden dimana 22 orang atau 39,29\% yang menjawab setuju, 20 orang atau 35,71\% menjawab sangat setuju, 10 orang atau 17,86\% menjawab ragu-ragu, dan 4 orang 7,14\% menjawab tidak setuju jika karyawan bekerja selalu memperhatikan ketepatan, ketelitian, ketrampilan, kebersihan hasil kerja. 
Tabel 4.3.

Distribusi Frekuensi Tanggapan Responden Tentang karyawan selalu memenuhi instruksi, serta memiliki inisiatif dalam bekerja, penuh kehati-hatian dan saling bekerja sama

\begin{tabular}{|c|c|c|c|}
\hline No & Jawaban Responden & Frekuensi & Persentase \\
\hline 1. & Sangat Setuju & 20 & $35.71 \%$ \\
\hline 2. & Setuju & 31 & $55.36 \%$ \\
\hline 3. & Ragu - Ragu & 5 & $8.93 \%$ \\
\hline 4. & Tidak Setuju & - & - \\
\hline 5. & Sangat Tidak Setuju & - & - \\
\hline \multicolumn{2}{|r|}{ Jumlah } & 56 & $100 \%$ \\
\hline
\end{tabular}

Dari tabel 4.3 diatas menunjukan tanggapan responden adalah setuju jika karyawan selalu memenuhi instruksi, serta memiliki inisiatif dalam bekerja, penuh kehatihatian dalam bekerja, dan saling bekerjasama. Hal ini terlihat pada jawaban responden dimana 31 orang atau 55,36\% yang menjawabsetuju, 20 orang atau 35,71\% menjawab sangat setuju dan 5 orang atau 8,93\% menjawab ragu-ragu jika karyawan selalu memenuhi instruksi, serta memiliki inisiatif dalam bekerja, penuh kehati-hatian dalam bekerja, dan saling bekerjasama.

Tabel 4.4

Distribusi Frekuensi Tanggapan Responden Tentang karyawan memiliki kemampuan dapat mengenali masalah dan menyelesaikan masalah pekerjaan

\begin{tabular}{|c|c|c|c|}
\hline No & Jawaban Responden & Frekuensi & Persentase \\
\hline 1. & Sangat Setuju & 7 & $12.50 \%$ \\
\hline 2. & Setuju & 40 & $71.43 \%$ \\
\hline 3. & Ragu - Ragu & 8 & $14.29 \%$ \\
\hline 4. & Tidak Setuju & 1 & $1.79 \%$ \\
\hline 5. & Sangat Tidak Setuju & - & - \\
\hline \multicolumn{2}{|r|}{ Jumlah } & 56 & $100 \%$ \\
\hline
\end{tabular}

Dari tabel 4.4 diatas menunjukan tanggapan responden adalah setuju jika karyawan memiliki kemampuan dapat mengenali masalah dan menyelesaikan masalah pekerjaan. Hal ini terlihat pada jawaban responden dimana 40 orang atau 71,43\% yang menjawab setuju, 8 orang atau 14,29\% menjawab ragu-ragu, 7 orang atau $12,50 \%$ menjawab sangat setuju, dan 1 orang $1,79 \%$ menjawab tidak setuju jika karyawan memiliki kemampuan dapat mengenali masalah dan menyelesaikan masalah pekerjaan. 
Tabel 4.5.

Distribusi Frekuensi Tanggapan Responden Tentang karyawan bersedia melakukan tugas tanpa adanya paksaan

\begin{tabular}{|c|c|c|c|}
\hline No & Jawaban Responden & Frekuensi & Persentase \\
\hline 1. & Sangat Setuju & 30 & $53.57 \%$ \\
\hline 2. & Setuju & 24 & $42.86 \%$ \\
\hline 3. & Ragu - Ragu & 2 & $3.57 \%$ \\
\hline 4. & Tidak Setuju & - & - \\
\hline 5. & Sangat Tidak Setuju & - & - \\
\hline & Jumlah & 56 & $100 \%$ \\
\hline
\end{tabular}

Dari tabel 4.5 diatas menunjukan tanggapan responden adalah sangat setuju jika karyawan bersedia melakukan tugas tanpa adanya paksaan. Hal ini terlihat pada jawaban responden dimana 30 orang atau 53,57 \% yang menjawab sangat setuju, 24 orang atau $42,86 \%$ menjawab setuju dan 2 orang atau 3,57\% menjawab ragu-ragu jika karyawan bersedia melakukan tugas tanpa adanya paksaan.

\section{Tabel 4.6.}

Distribusi Frekuensi Tanggapan Responden Tentang karyawan memiliki sikap atau perilaku yang baik terhadap atasan atau teman kerja

\begin{tabular}{|c|c|c|c|}
\hline No & Jawaban Responden & Frekuensi & Persentase \\
\hline 1. & Sangat Setuju & 23 & $41.07 \%$ \\
\hline 2. & Setuju & 26 & $46.43 \%$ \\
\hline 3. & Ragu - Ragu & 5 & $8.93 \%$ \\
\hline 4. & Tidak Setuju & 2 & $3.57 \%$ \\
\hline 5. & Sangat Tidak Setuju & - & - \\
\hline \multicolumn{2}{|r|}{ Jumlah } & 56 & $100 \%$ \\
\hline
\end{tabular}

Dari tabel 4.6 diatas menunjukan tanggapan responden adalah setuju jika karyawan memiliki sikap atau perilaku yang baik terhadap atasan atau teman kerja. Hal ini terlihat pada jawaban responden dimana 26 orang atau 46,43\% yang menjawab setuju, 23 orang atau 41,07 \% menjawab sangat setuju, 5 orang atau 8,93\% menjawab ragu-ragu, dan 2 orang 3,57\% menjawab tidak setuju jika karyawan memiliki sikap atau perilaku yang baik terhadap atasan atau teman kerja.

Tabel 4.7.

Distribusi Frekuensi Tanggapan Responden Tentang tingkat kehadiran karyawan melebihi dari tingkat kehadiran karyawan lainnya

\begin{tabular}{|c|c|c|c|}
\hline No & Jawaban Responden & Frekuensi & Persentase \\
\hline 1. & Sangat Setuju & 12 & $21.43 \%$ \\
\hline 2. & Setuju & 37 & $66.07 \%$ \\
\hline 3. & Ragu - Ragu & 7 & $12.50 \%$ \\
\hline 4. & Tidak Setuju & - & - \\
\hline 5. & Sangat Tidak Setuju & - & - \\
\hline \multicolumn{2}{|r|}{ Jumlah } & 56 & $100 \%$ \\
\hline
\end{tabular}


Dari tabel 4.7 diatas menunjukan tanggapan responden adalah setuju jika tingkat kehadiran karyawan melebihi dari tingkat kehadiran karyawan lainnya. Hal ini terlihat pada jawaban responden dimana 37 orang atau 66,07 \% yang menjawab setuju, 12 orang atau $21,43 \%$ menjawab sangat setuju dan 7 orang atau 12,50\% menjawab ragu-ragu jika tingkat kehadiran karyawan melebihi dari tingkat kehadiran karyawan lainnya.

b. Promosi Jabatan(Y)

Tabel 4.8.

Distribusi Frekuensi Tanggapan Responden Tentang karyawan memiliki pengalaman kerja yang dapat dijadikan syarat dalam promosi jabatan

\begin{tabular}{|c|c|c|c|}
\hline No & Jawaban Responden & Frekuensi & Persentase \\
\hline 1. & Sangat Setuju & 19 & $33.93 \%$ \\
\hline 2. & Setuju & 33 & $58.93 \%$ \\
\hline 3. & Ragu - Ragu & 4 & $7.14 \%$ \\
\hline 4. & Tidak Setuju & - & - \\
\hline 5. & Sangat Tidak Setuju & - & - \\
\hline \multicolumn{2}{|r|}{ Jumlah } & 56 & $100 \%$ \\
\hline
\end{tabular}

Dari tabel 4.8 diatas menunjukan tanggapan responden adalah setuju jika karyawan memiliki pengalaman kerja yang dapat dijadikan syarat dalam promosi jabatan. Hal ini terlihat pada jawaban responden dimana 33 orang atau 58,93\% yang menjawab setuju, 19 orang atau 33,93\% menjawab sangat setuju, dan 4 orang atau 7,14\% menjawab ragu-ragu jika karyawan memiliki pengalaman kerja yang dapat dijadikan syarat dalam promosi jabatan.

Tabel 4.9.

Distribusi Frekuensi Tanggapan tentang karyawan memiliki kecakapan dalam bekerja

\begin{tabular}{|c|c|c|c|}
\hline No & Jawaban Responden & Frekuensi & Persentase \\
\hline 1. & Sangat Setuju & 24 & $42.86 \%$ \\
\hline 2. & Setuju & 29 & $51.79 \%$ \\
\hline 3. & Ragu - Ragu & 2 & $3.57 \%$ \\
\hline 4. & Tidak Setuju & 1 & $1.79 \%$ \\
\hline 5. & Sangat Tidak Setuju & - & - \\
\hline \multicolumn{2}{|r|}{ Jumlah } & 56 & $100 \%$ \\
\hline
\end{tabular}

Dari tabel 4.9 diatas menunjukan tanggapan responden adalah setuju jika karyawan memiliki kecakapan dalam bekerja. Hal ini terlihat pada jawaban responden dimana 29 orang atau 51,79\% yang menjawab setuju, 24orang atau 42,86\% menjawab sangat setuju, 2 orang atau 3,57\% menjawab ragu-ragu, dan 1 orang 1,79\% menjawab tidak setuju jika karyawan memiliki kecakapan dalam bekerja . 
Tabel 4.10.

Distribusi Frekuensi Tanggapan Responden Tentang karyawan memiliki tingkat disiplin yang tinggi dalam bekerja agar dapat mencapai hasil yang optimal

\begin{tabular}{|c|c|c|c|}
\hline No & Jawaban Responden & Frekuensi & Persentase \\
\hline 1. & Sangat Setuju & 14 & $25.00 \%$ \\
\hline 2. & Setuju & 41 & $73.21 \%$ \\
\hline 3. & Ragu - Ragu & 1 & $1.79 \%$ \\
\hline 4. & Tidak Setuju & - & - \\
\hline 5. & Sangat Tidak Setuju & - & - \\
\hline \multicolumn{2}{|r|}{ Jumlah } & 56 & $100 \%$ \\
\hline
\end{tabular}

Dari tabel 4.10 diatas menunjukan tanggapan responden adalah setuju jika karyawan memiliki tingkat disiplin yang tinggi dalam bekerja agar dapat mencapai hasil yang optimal. Hal ini terlihat pada jawaban responden dimana 41 orang atau 73,21\% yang menjawabsetuju, 14 orang atau $25,00 \%$ menjawab sangat setuju, dan 1 orang atau 1,79\% menjawab ragu-ragu.

Tabel 4.11.

Distribusi Frekuensi Tanggapan Responden Tentang karyawan memilki tingkat pendidikan yang baik dibandingkan dengan rekan kerja lainnya

\begin{tabular}{|c|c|c|c|}
\hline No & Jawaban Responden & Frekuensi & Persentase \\
\hline 1. & Sangat Setuju & 26 & $46.43 \%$ \\
\hline 2. & Setuju & 27 & $48.21 \%$ \\
\hline 3. & Ragu - Ragu & 3 & $5.36 \%$ \\
\hline 4. & Tidak Setuju & - & - \\
\hline 5. & Sangat Tidak Setuju & - & - \\
\hline \multicolumn{2}{|r|}{ Jumlah } & 56 & $100 \%$ \\
\hline
\end{tabular}

Dari tabel 4.11 diatas menunjukan tanggapan responden adalah setuju jika karyawan memilki tingkat pendidikan yang baik dibandingkan dengan rekan kerja lainnya. Hal ini terlihat pada jawaban responden dimana 27 orang atau 48,21 \% yang menjawabsetuju,26 orang atau 46,43\% menjawab sangat setuju, dan 3 orang atau 5,36 \% menjawab ragu-ragu jika karyawan memilki tingkat pendidikan yang baik dibandingkan dengan rekan kerja lainnya.

Tabel 4.12.

Distribusi Frekuensi Tanggapan Responden Tentang karyawan merasa puas dengan promosi yang selama ini diterapkan oleh kantor

\begin{tabular}{|c|c|c|c|}
\hline No & Jawaban Responden & Frekuensi & Persentase \\
\hline 1. & Sangat Setuju & 24 & $42.86 \%$ \\
\hline 2. & Setuju & 26 & $46.43 \%$ \\
\hline 3. & Ragu - Ragu & 6 & $10.71 \%$ \\
\hline 4. & Tidak Setuju & - & - \\
\hline 5. & Sangat Tidak Setuju & - & - \\
\hline \multicolumn{2}{|r|}{ Jumlah } & 56 & $100 \%$ \\
\hline
\end{tabular}


Dari tabel 4.12 diatas menunjukan tanggapan responden adalah sangat setuju jika karyawan merasa puas dengan promosi yang selama ini diterapkan oleh kantor. Hal ini terlihat pada jawaban responden dimana 26 orang atau $46,43 \%$ yang menjawabsetuju, 24 orang atau 42,86\% menjawab sangat setuju, dan 6 orang atau 10,71\% menjawab raguragu jika karyawan merasa puas dengan promosi yang selama ini diterapkan oleh kantor.

Tabel 4.13.

Distribusi Frekuensi Tanggapan Responden Tentang karyawan selalu memilki loyalitas yang tinggi terhadap perusahaan

\begin{tabular}{|c|c|c|c|}
\hline No & Jawaban Responden & Frekuensi & Persentase \\
\hline 1. & Sangat Setuju & 24 & $42.86 \%$ \\
\hline 2. & Setuju & 31 & $55.36 \%$ \\
\hline 3. & Ragu - Ragu & 1 & $1.79 \%$ \\
\hline 4. & Tidak Setuju & - & - \\
\hline 5. & Sangat Tidak Setuju & - & - \\
\hline \multicolumn{2}{|r|}{ Jumlah } & 56 & $100 \%$ \\
\hline
\end{tabular}

Dari tabel 4.13 diatas menunjukan tanggapan responden adalah sangat setuju jika karyawan selalu memilki loyalitas yang tinggi terhadap perusahaan . Hal ini terlihat pada jawaban responden dimana 31 orang atau 55,36 \% yang menjawabsetuju,24 orang atau $42,86 \%$ menjawab sangat setuju, dan 1 orang atau 1,79\% menjawab ragu-ragu.

Tabel 4.14.

Distribusi Frekuensi Tanggapan Responden Tentang promosi jabatan yang diterapkan perusahaan dapat memotivasi karyawan untuk berprestasi dalam bekerja

\begin{tabular}{|c|c|c|c|}
\hline No & Jawaban Responden & Frekuensi & Persentase \\
\hline 1. & Sangat Setuju & 12 & $21.43 \%$ \\
\hline 2. & Setuju & 39 & $69.64 \%$ \\
\hline 3. & Ragu - Ragu & 3 & $5.36 \%$ \\
\hline 4. & Tidak Setuju & 2 & $3.57 \%$ \\
\hline 5. & Sangat Tidak Setuju & - & - \\
\hline \multicolumn{2}{|r|}{ Jumlah } & 56 & $100 \%$ \\
\hline
\end{tabular}

Dari tabel 4.14 diatas menunjukan tanggapan responden adalah setuju jika promosi jabatan yang diterapkan perusahaan dapat memotivasi karyawan untuk berprestasi dalam bekerja. Hal ini terlihat pada jawaban responden dimana 39 orang atau 69,64\% yang menjawab setuju, 12 orang atau 21,43\% menjawab sangat setuju, 3 orang atau 5,36 $\%$ menjawab ragu-ragu, dan 2 orang 3,57 \% menjawab tidak setuju jika promosi jabatan yang diterapkan perusahaan dapat memotivasi karyawan untuk berprestasi dalam bekerja. 
2. Hasil Pembahasan Analisis Statistik

a. Uji Validitas dan Uji Reliabilitas

1. Uji Validitas

Uji validitas digunakan untuk menguji sejauh mana ketepatan alat pengukur dapat mengungkapkan konsep gejala/kejadian yang diukur. Item kuesioner dinyatakan valid apabila nilai $r$ hitung $>0,30$. Pengujian validitas selengkapnya dapat dilihat pada tabel 4.15 berikut ini :

Tabel 4.15

Hasil Uji Validitas

\begin{tabular}{|c|l|c|c|}
\hline No & \multicolumn{1}{|c|}{ Variabel } & Pearson Correlation & Ket \\
\hline 1. & Prestasi Kerja (X): & & \\
& - P1 & 0,629 & Valid \\
& - P2 & 0,561 & Valid \\
& - P3 & 0,513 & Valid \\
& - P4 & 0,551 & Valid \\
& - P5 & 0,440 & Valid \\
& - P6 & 0,634 & Valid \\
\hline 2. P7 & Promosi Jabatan (Y): & 0,570 & Valid \\
& - P1 & 0,584 & \\
& - P2 & 0,585 & Valid \\
& - P3 & 0,506 & Valid \\
& - P4 & 0,531 & Valid \\
& - P5 & 0,380 & Valid \\
& - P6 & 0,505 & Valid \\
& - P7 & 0,357 & Valid \\
\hline
\end{tabular}

Sumber : Data Olahan Statistik, 2014

Pada Tabel 4.15 terlihat bahwa korelasi antara masing-masing indikator menunjukan semua variabel di dalam penelitian adalah valid, hal tersebut dapat dilihat dari nilai $\quad r$ hitung $>0,30$. Sehingga dapat disimpulkan bahwa semua item pertanyaan dinyatakan valid.

2. Uji Reabilitas

Uji reliabilitas digunakan untuk menguji sejauh mana keandalan suatu alat pengukur untuk dapat digunakan lagi untuk penelitian yang sama. Pengujian reliabilitas dalam penelitian ini adalah dengan menggunakan rumus Alpha. Dalam melakukan uji reliabilitas digunakan metode pengukuran Reliabilitas Alpha Cronbach $(\alpha)$ karena setiap butir pernyataan menggunakan skala pengukuran interval. Suatu instrument dapat dikatakan reliable/handal apabila memiliki nilai 
Alpha $(\alpha)$ lebih besar dari 0,60 Hasil pengujian reliabilitas untuk masing-masing variabel yang diringkas pada tabel 4.16 berikut ini:

Tabel 4.16

Hasil Uji Reabilitas

\begin{tabular}{|c|l|c|c|}
\hline No & \multicolumn{1}{|c|}{ Variabel } & $\begin{array}{c}\text { Corrected Item- } \\
\text { Total Correlation }\end{array}$ & Ket \\
\hline 1. & Prestasi Kerja (X): & 0,625 & Realibel \\
& - P1 & 0,793 & Realibel \\
& - P2 & 0,633 & Realibel \\
& - P3 & 0,695 & Realibel \\
& - P4 & 0,747 & Realibel \\
& - P5 & 0,609 & Realibel \\
& - P6 & 0,660 & Realibel \\
\hline 2. & Promosi Jabatan (Y): & 0,616 & \\
& - P1 & 0,618 & Realibel \\
& - P2 & 0,752 & Realibel \\
& - P3 & 0,694 & Realibel \\
& - P4 & 0,729 & Realibel \\
& - P5 & 0,711 & Realibel \\
& - P6 & 0,772 & Realibel \\
\hline
\end{tabular}

Sumber : Data Olahan Statistik, 2017

Hasil uji reliabilitas tersebut menunjukkan bahwa semua variabel mempunyai koefisien Alpha yang cukup besar yaitu diatas 0,60 sehingga dapat dikatakan semua konsep pengukur masing-masing variabel dari kuesioner adalah reliabel sehingga untuk selanjutnya item-item pada masing-masing konsep variabel tersebut layak digunakan sebagai alat ukur.

b. Pengujian Regresi Linear Sederhana

Berdasarkanhasilkuesioner responden maka dilakukan analisisdatadengan menggunakan model analisis regresi linear sederhana, dalam hal ini adalah pengaruh prestasi kerja (X)sebagaivariabel bebas (independent) yang dinyatakan dengan variabel $\mathrm{X}$ dan promosi jabatan dinyatakan sebagai variabel $\mathrm{Y}$ (dependent).

Hasil perhitungan uji statistik menunjukan bahwa koefisien regresi untuk variabel prestasi kerja $(\mathrm{X})=0,393$ sedangkan konstant koefisien regresi sebesar 2,774 sehingga apabila dimasukan dalam persamaan regresi akan diperoleh persamaan koefisien regresi sebagai berikut :

$$
Y=2,774+0,393 X
$$


Dari hasil analisis dapat dilihat pada tabel 4.20 yaitu :

Tabel 4.17

Hasil Analisis Regresi Linear Berganda 2 Prediktor

\begin{tabular}{|c|c|c|c|c|}
\hline Variabel Bebas & $\begin{array}{c}\text { Koefisien } \\
\text { Regresi (B) }\end{array}$ & $\begin{array}{c}\text { Standar } \\
\text { Error }\end{array}$ & $\mathrm{t}{ }^{-}$Hitung & $\begin{array}{c}\text { Signifikan } \\
\mathrm{t}\end{array}$ \\
\hline Prestasi Kerja (X) & 0,393 & 0,118 & 3,317 & 0,002 \\
\hline Constanta & 2,774 & & & \\
\hline $\mathrm{R}$ & 0,441 & \multirow{3}{*}{\multicolumn{3}{|c|}{$\mathrm{F}_{\text {Ratio }} / \mathrm{F}_{\text {Hitung }}=11,002$}} \\
\hline R Square & 0,169 & & & \\
\hline Adjusted R Square R & 0,154 & & & \\
\hline
\end{tabular}

Sumber : Hasil Olahan Data Statistik, 2017

Persamaan regresi linear sederhana tersebut selanjutnya dapat dilakukan uji hipotesis dengan melakukan uji-t Untuk mengetahui tingkat probabilitas yang dapat menentukan signifikan variabel koefisien regresi, dengan membandingkan nilai thitung dengan t-tabel. Jika t-hitung lebih besar dari t-tabel artinya variabel independent $(\mathrm{X})$ berupa pengaruh prestasi kerja $(\mathrm{X})$ memberi pengaruh secara parsial terhadap promosi jabatan (Y) begitu pula sebaliknya.

c. Penjelasan Hasil Uji-t Statistik

Di sisi lain untuk menguji hipotesis pengaruhnya secara parsial (masing - masing) digunakan uji-thitung dengan kaidah dengan asumsi bahwa:

1. Jika t-hitung > t-tabel, pada tingkat kepercayaan 95\% atau taraf signifikansi $5 \%$ $(0,05)$, maka sebuah variabel bebas yakni prestasi kerja secara parsial berpengaruhterhadap promosi jabatan.

2. Jika t-hitung < t-tabel,pada tingkat kepercayaan $95 \%$ atau taraf signifikansi $5 \%$ $(0,05)$, maka semua variabel bebas yakni prestasi kerja secara parsial tidak berpengaruh terhadap promosi jabatan.

Untuk membuktikan hal tersebut maka terlebih dahulu tentukan tingkat derajat kebebasan derajat kebebasan (degrees of freedom) atau $\mathrm{df}=\mathrm{n}-1=56-1=55$ maka diperoleh $\mathrm{t}$-tabel $=2,000$.

Untuk menunjukan bahwa dari variabel bebas (X) yaitu prestasi kerja berpengaruh parsial terhadap promosi jabatan (Y) pada PDAM Kabupaten Banggai. Hal tersebut dapat diuraikan sebagai berikut :

Prestasi kerja merupakan salah satu bagian yang mempengaruhi promosi jabatan, hasil penelitian diatas menunjukan bahwa variabel prestasi kerja mempunyai pengaruh positif, karena diperoleh nilai koefisien regresi sebesar 0,393 yang berarti bahwa prestasi kerja memberikan pengaruh positif terhadap promosi jabatan sebesar 
39,3\%, dengan kata lain jika prestasi kerja ditingkatkan maka promosi jabatan akan meningkat sebesar 39,3\% dengan asumsi faktor lain adalah konstan.

Namun untuk melihat seberapa besar tingkat signifikannya, dapat di lihat pada Uji-t, dimana Uji-t menunjukan t-hitung $=3,317>\mathrm{t}$-tabel $=2,000$, yang berarti bahwa variabel prestasi kerja berpengaruh signifikan terhadap promosi jabatan pada PDAM Kabupaten Banggai.

Dengan demikian bahwa terdapat pengaruh secara parsial antaravariabel prestasi kerja $(\mathrm{X})$ terhadap promosi jabatan $(\mathrm{Y})$ pada PDAM Kabupaten Banggai, sehingga hipotesis dinyatakan terbukti.

Untuk lebih jelasnya dapat dilihat pada tabel berikut ini :

Tabel 4.18

Pengaruh Dari Variabel Bebas Terhadap promosi Jabatan Pada PDAM Kabupaten Banggai.

\begin{tabular}{|l|c|c|}
\hline \multicolumn{1}{|c|}{ Variabel Bebas } & Koefisien Regresi & t-hitung : t-tabel \\
\hline Prestasi kerja $(\mathrm{X})$ & 0,393 & $3,317>2,000$ \\
\hline
\end{tabular}

Sumber : Hasil Olahan Data Statistik, 2017

d. Analisis Koefisien Korelasi Produk Moment

Untuk mengetahui bagaimana hubungan dari variabel $\mathrm{X}$ terhadap variabel $\mathrm{Y}$, maka digunakan analisis korelasi. Untuk memberikan jawaban terhadap hipotesis dapat dilihat olah data SPSS 19 menunjukan bahwa koefisien korelasi berganda (R) adalah sebesar 0,411 atau 41,1\%, ini berarti bahwa korelasi atau hubungan kedua variabel yaitu prestasi kerja (X)terhadap promosi jabatan (Y) adalahcukup kuat.

Tabel 4.19

Koefisien Korelasi Produk Moment

\begin{tabular}{|c|c|c|}
\hline $\begin{array}{c}\text { Interval } \\
\text { Koefisien }\end{array}$ & Koefisien Korelasi & Tafsirannya \\
\hline $0,00-0,199$ & + dan - & Hubungan Sangat Rendah \\
\hline $0,20-0,399$ & + dan - & Hubungan Rendah \\
\hline $0,40-0,599$ & 0,411 & Hubungan Cukup Kuat \\
\hline $0,60-0,799$ & + dan - & Hubungan Kuat \\
\hline $0,80-1,000$ & + dan - & Hubungan Sangat Kuat \\
\hline
\end{tabular}

Sedangkan Nilai R square adalah nilai pengkuadratan dari nilai korelasi atau biasa yang disebut koefisien determinasi yang bertujuan mengetahui seberapa besar variabel $\mathrm{X}$ berpengaruh terhadap variabel $\mathrm{Y}$.

Besarnya koefisien determinasi atau adjust $\mathrm{R}$ square sebesar 0,154 , sehingga koefisien determinasi $\mathrm{R}^{2}$ adalah sebesar 15,4 \%, ini berarti bahwa sebesar 15,4\% dari variabel bebas yaitu prestasi kerja (X) memberikan kontribusi terhadap promosi 
jabatan (Y) pada PDAM Kabupaten Banggai, sedangkan sisanya $(100 \%$ - 15,4\% = $84,6 \%$ ) adalah merupakan variabel lain yang mempengaruhi promosi jabatan (Y), yang tidak diteliti di dalam penelitian ini.

\section{Pembahasan}

Hasil penelitian ini menunjukkan bahwa prestasi kerja berpengaruh terhadap promosi jabatan pada PDAM Kabupaten Banggai. Dimana variabel prestasi kerja (X) mempengaruhi promosi jabatan secara positif dan signifikan, hal ini dapat dilihat bahwa nilai koefisien regresi sebesar 0,393 yang berarti bahwa prestasi kerja memberikan pengaruh positif terhadap promosi jabatan sebesar 39,3\%, dan berpengaruh signifikan karena Uji-t menunjukan t-hitung $=3,317>\mathrm{t}$-tabel $=2,000$ yang berarti bahwa hipotesis terbukti dan dapat diterima, dimana variabel prestasi kerja berpengaruh positif dan signifikan terhadap promosi jabatan.

Dari hasil pembahasan di atas, dapat diketahui bahwa prestasi kerja memiliki pengaruh positif dan signifikan terhadap promosi jabatan karyawan, kaitannya dengan permasalahan yang terjadi pada kantor PDAM Kabupatn Banggai yaitu masih banyaknya karyawan Perusahaan Daerah Air Minum (PDAM) Kabupaten Banggai bekerja dengan seenaknya, kurang memanfaatkan waktu yang ada untuk mengembangkan diri, lebih suka berbincang-bincang dengan rekan sekerja daripada menyelesaikan karyawan, sehingga hal ini akan mempengaruhi prestasi kerjanya. Sehingga banyak karyawan Perusahaan Daerah Air Minum (PDAM) Kabupaten Banggai yang jarang mendapatkan promosi jabatan ke tingkat yang lebih tinggi. dari permasalahan tersebut, maka hendaknya Pimpinan PDAM Kabupaten Banggai dapat mengambil keputusan tentang layak atau tidak layaknya karyawan tersebut dipromosikan, Pimpinan PDAM Kabupaten Banggai dapat menilai karyawan dengan transparan dan melihat dari beberapa catatan yang ada untuk membantu penilaian karyawan tersebut, proses penilaian prestasi kerja karyawan sebaiknya dilakukan secara terbuka atau transparan serta dalam melaksanaan promosi jabatan hendaknya pimpinan memperhatikan kualitas dan kemampuan karyawan hal ini penting karena PDAM Kabupaten Banggai adalah Badan Usaha Milk Daerah yang memiliki kewajiban melayani masyarakat. dari penjelasan diatas menunjukkan bahwa PDAM Kabupaten Banggai perlu melakukan penilaian prestasi kerja karyawan yang bermanfaat untuk perbaikan prestasi kerja karyawan, penyesuaian kompensasi, keputusan penempatan, kebutuhan untuk latihan dan pengembangan, perencanaan pengembangan karier, penyimpangan proses staffing, ketidakakuratan informasional, kesalahan desain pekerjaan, 
kesempatan kerja yang adil, dan tantangan eksternal.Penilaian sering tidak melibatkan emosional dalam menilai prestasi kerja karyawan ini dapat menyebabkan evaluasi penilaian menjadi bias,jadi, dengan penilaian prestasi kerja dapatlah diketahui prestasi kerja seorang karyawan baik itu kelebihan maupun kekurangan yang dimiliki karyawan.

Bagi karyawan PDAM Kabupaten Banggai yang berprestasi kerja tinggi akan memungkinkan diri untuk dipetimbangkan jika diadakan promosi jabatan. Dan bagi karyawan yang menunjukan prestasi kerja yang rendah dapat memperbaiki prestasi kerjanya dengan cara dipindahkan ketempat atau kedudukan yang sesuai dengan kemampuannya. Atau bisa juga PDAM Kabupaten Banggai memberikan pendidikan dan pelatihan agar kemampuan karyawan dapat bertambah serta dengan pemberian saransaran. Dan mungkin juga karyawan tersebut dapat diberhentikan.

Hal ini sesuai pendapat Hasibuan (2006), bahwa Prestasi kerja juga dapat digunakan perusahaan untuk mengetahui kekurangan dan potensi seorang karyawan. Dari hasil tersebut, perusahaan dapat mengembangkan suatu perencanaan sumber daya manusia secara menyeluruh dalam menghadapi masa depan perusahaan. Prinsip "The right man in the right place" harus dipenuhi agar perusahaan dapat berjalan dengan efisien dan efektif. Mengingat pentingnya pengaruh prestasi kerja ini dalam keputusan mengenai promosi karyawan.

Sedangkan Nitisemito (2002) menjelaskan mengenai adanya suatu nilai yang bertambah kedalam pengertian promosi jabatan, yaitu promosi jabatan adalah proses pemindahan karyawan dari suatu jabatan ke jabatan lain yang lebih tinggi. Promosi akan tugas tanggung jawab dan wewenang yang lebih tinggi. Promosi akan diikuti dengn tugas tanggung jawab dan wewenang yang lebih tinggi dari jabatan yang diikuti sebelumnya. Dan pada umumnya promosi juga diikuti dengan peningkatan income(pendapatan) dan fasilitas lain. Tetapi promosi sendiri sebenarnya memiliki nilai karena promosi merupakan bukti pengakuan antara lain terhadap prestasinya.

\section{PENUTUP}

\section{Simpulan}

Berdasarkan hasil penelitian dan pembahasan yang telah dikemukakan, maka dapat disimpulkan sebagai berikut :

1. Hasil perhitungan uji statistik menunjukan bahwa koefisien regresi untuk variabel prestasi kerja $(X)=0,393$ sedangkan konstant koefisien regresi sebesar 2,774 
sehingga apabila dimasukan dalam persamaan regresi akan diperoleh persamaan koefisien regresi sebagai berikut $Y=2,774+0,393 \mathrm{X}$

2. Hasil penelitian menunjukan bahwa prestasi kerja $(\mathrm{X})$ mempunyai pengaruh positif, karena diperoleh nilai koefisien regresi sebesar 0,393 yang berarti bahwa prestasi kerja memberikan pengaruh positif terhadap promosi jabatan sebesar 39,3\% dan untuk melihat seberapa besar tingkat signifikannya, dapat di lihat pada Uji-t, dimana Uji-t menunjukan t-hitung $=3,317>\mathrm{t}$-tabel $=2,000$, yang berarti bahwa variabel prestasi kerja berpengaruh signifikan terhadap promosi jabatan pada PDAM Kabupaten Banggai. Dengan demikianbahwa terdapat pengaruh secara parsial antara variabel prestasi kerja (X) terhadap promosi jabatan (Y) pada Kantor PDAM Kabupaten Banggai, sehingga hipotesis terbukti.

3. berdasarkan dari analisis korelasi diperoleh hasil bahwa koefisien korelasi berganda (R) adalah sebesar 0,411 atau 41,1\%, ini berarti bahwa korelasi atau hubungan kedua variabel yaitu prestasi kerja (X) terhadap promosi jabatan (Y) adalah cukup kuat.

4. Besarnya koefisien determinasi atau adjust $\mathrm{R}$ square sebesar 0,154 , sehingga koefisien determinasi $\mathrm{R}^{2}$ adalah sebesar 15,4\%, ini berarti bahwa sebesar 15,4\% dari variabel bebas yaitu prestasi kerja $(\mathrm{X})$ memberikan kontribusi terhadap promosi jabatan (Y) pada Kantor PDAM KabupatenBanggai, sedangkan sisanya (100\% - 15,4 $\%=84,6 \%$ ) adalah merupakan faktor lain yang mempengaruhi promosi jabatan $(\mathrm{Y})$, yang tidak diteliti di dalam penelitian ini.

\section{Saran}

1. Diharapkan Pimpinan PDAM Kabupaten Banggai dapat mengambil keputusan tentang layak atau tidak layaknya karyawan tersebut dipromosikan, Pimpinan PDAM Kabupaten Banggai dapat menilai karyawan dengan transparan dan melihat dari beberapa catatan yang ada untuk membantu penilaian karyawan tersebut.

2. Dalam melaksanaan promosi jabatan hendaknya memperhatikan kualitas dan kemampuan karyawan hal ini penting karena PDAM Kabupaten Banggai adalah Badan Usaha Milk Daerah yang memiliki kewajiban melayani masyarakat.

\section{DAFTAR PUSTAKA}

Algifari. (2002). Analisis Regresi, Teori, Kasus \& Solusi. BPFE UGM, Yogyakarta. 
Arikunto, S., (2002), Prosedur Penelitian Suatu Pendekatan Praktik, cetakan kelima, PT. Bina Aksara, Jakarta.

As'ad M. (2005). Psykologi SDM. Liberty, Edisi Revisi, Yogyakarta.

Dharma, Agus, (2005). Gaya Kepemimpinan yang Efektif bagi Manager, Edisi Kedelapan, Penerbit CV. Sinar Baru, bandung

Flippo, E.B., (2001), Manajemen SDM, Cetakan Ketiga, Erlangga, Jakarta.

Hasibuan, Melayu, SP., (2006),Manajemen Sumber Daya Manusia, Bumi Aksara, Jakarta

Heidrahman dan Suad Husnan, (2005), Manajamen Sumber Daya Manusia, Edisi Kedua, STIE YKPN, Yogyakarta

Moekijat (2004). Manajemen Personalia Edisi 3. Yogyakarta : BPEE.

Nitisemito, Alex. S. (2002), Manajemen Suatu Dasar dan Pengantar, Penerbit Ghalia Indonesia, Jakarta

Rao, TV, (2001). Performance Appraisal Theory and Practice. Diterjemahkan oleh L. Mulyana, Penilaian Prestasi Kerja: Teori dan Praktek, seri Manajemen No. 125, Penerbit PT. Gramedia, Jakarta.

Sedarmayanti, (2006), Manajemen Sumber Daya Manusia, Jakarta, Penerbit PT. Rineka Cipta.

Samsudin (2005). Manajemen Sumber Daya Manusia. Yogyakarta : Graha Ilmu

Siagian, Sondang P., (2000), Teori, Motivasi dan Aplikasinya, Cetakan Kelima, Rineka Cipta, Jakarta

Syarif, Rusli, (2003), Teknik Manajemen Latihan dan Pengembangan, Edisi Kelima,Angkasa, Bandung

Sugiyono, (2005). Statistik Untuk Penelitian. Cetakan Kedua. Penerbit CV. Alpha Beta. Bandung.

Wayne, (2002), Manajemen. Edisi Bahasa Indonesia, Alih Bahasa Alexander Sindoro, Prenhallindo Jakarta 